\title{
The Programmatic Approach: Finding the Right Balance between the Precautionary Principle and the Right to Conduct a Business
}

\author{
Rogier Kegge \\ Assistant professor of Administrative and Environmental Law \\ Leiden University, the Netherlands \\ r.kegge@law.leidenuniv.nl
}

Annemarie Drahmann

Associate professor of Administrative and European Law

Leiden University, the Netherlands

a.drahmann@law.leidenuniv.nl

\begin{abstract}
This article aims to assess whether a programmatic approach could still be a useful legal instrument for the allocation of scarce environmental rights and a legitimate tool for implementing EU Directives. In response to the recent judgment of the Court of Justice of the European Union (CJEU) in the Dutch Programmatic Approach to Nitrogen case, ${ }^{1}$ we will examine under what conditions a programmatic approach could be compatible with the precautionary principle and the freedom to conduct a business as protected by EU law. These principles are inextricably linked, and the Member States and the CJEU must find a balance between a high level of environmental protection and the freedom to conduct a business.
\end{abstract}

1 Joined cases C-293/17 and C-294/17, Coöperatie Mobilisation for the Environment UA a.o. $v$ College van gedeputeerde staten van Noord-Brabant, ECLI:EU:C:2018:882 (Programmatic Approach to Nitrogen, hereafter: PAS). 


\section{Keywords}

programmatic approach - Habitats Directive - precautionary principle - freedom to conduct a business

\section{Introduction}

This article aims to assess whether a programmatic approach could be a useful instrument for the allocation of scarce environmental rights. The recent judgment of the CJEU in the Dutch Programmatic Approach to Nitrogen case has shown that a programmatic approach is not a panacea for complex environmental problems. However, the CJEU did not put an end to this relatively new legal instrument either and even stated that an overall evaluation makes it possible to examine better the cumulative effects of various projects. ${ }^{2}$ In this article, we will examine under what conditions a programmatic approach could be compatible with both the precautionary principle as contained in the Treaty on the Functioning of the European Union (TFEU) and the Habitats Directive, ${ }^{3}$ and the freedom to conduct a business protected by the Charter of Fundamental Rights of the European Union (CFR). The precautionary principle and the freedom to conduct a business are inextricably linked, and the Member States and the CJEU must find a balance between a high level of environmental protection and the freedom to conduct a business. ${ }^{4}$

In this article we will first introduce the Dutch Programmatic Approach to Nitrogen (section 2), the programmatic approach in general (section 3 ) and the judgment of the CJEU in the Dutch Programmatic Approach to Nitrogen case (section 4). Subsequently, we will discuss whether a programmatic approach could be in accordance with the precautionary principle (section 5 ) and the freedom to conduct a business (section 6). In section 7 we will conclude that with a programmatic approach Member States can find a balance between these two principles, since it can be used as an instrument to allocate scarce environmental rights proportionally and also offer the required high level of protection of the environment.

2 Supra note 1.

3 Council Directive 92/43/EEG on the conservation of natural habitats and of wild fauna and flora, OJ 1992 L2o6.

4 For instance, both the precautionary principle and the right to conduct a business are invoked in the Pillbox 38 case regarding regulations applicable to electronic cigarettes: C-477/14, Pillbox $38(U K)$ Ltd $v$ The Secretary of State for Health, ECLI:EU:C:2016:324. 


\subsection{Introduction to the Programmatic Approach to Nitrogen}

The Programmatic Approach to Nitrogen was a rather complex legal system with a twofold objective. ${ }^{5}$ On the one hand, the programmatic approach aimed to reduce nitrogen deposition in such a manner that vulnerable Natura 2000 sites would be able to recover from enduring excessive levels of nitrogen. Ultimately, this had to lead to the favourable conservation status as contained in the Habitats Directive. On the other hand, the programmatic approach also aimed to facilitate decision-making and to promote economic growth in the vicinity of Natura 2000 sites. This twofold objective is no new concept in the Netherlands and has been referred to as 'the Dutch approach'.6 The PAS included site-specific restoration measures as well as source-directed measures. In the PAs, it was assumed that the source-directed measures would cause a significant reduction of nitrogen deposition, in addition to the autonomous decrease of nitrogen deposition. This reduction was quantified as 'room for deposition'. A substantial part of this room for deposition was used for new economic activities, referred to as 'room for development'. This room for development was divided into two segments. The first segment consisted of a list of priority projects, such as large national infrastructural projects, and the second segment consisted of so-called 'free room for development'. This second segment provided for more local economic growth, such as the expansion of livestock farms, though only within the boundaries of the allocated room for development.

Instead of assessing each individual plan or project, in the PAs the total amount of nitrogen deposition was assessed. The PAS included three categories of projects. First, projects causing nitrogen deposition less than $0.05 \mathrm{~mol} /$ ha/yr did not need to obtain any prior authorization. Secondly, projects causing nitrogen deposition of more than $0.05 \mathrm{~mol} / \mathrm{ha} / \mathrm{yr}$, but less than $1 \mathrm{~mol} / \mathrm{ha} /$ yr were also permitted without prior authorization, but had to be notified. Finally, all projects causing nitrogen deposition of more than $1 \mathrm{~mol} / \mathrm{ha} / \mathrm{yr}$ required a permit. As long as there was sufficient room for deposition, projects could be allowed. This system meant that only authorized projects were registered by means of notification or permit. The projects under the threshold of

5 H. Schoukens, The Quest for the Holy Grail and the Dutch Integrated Approach to Nitrogen: How to Align Adaptive Management Strategies with the EU Nature Directives?, JEE PL, 2018 (15), p. $187-189$.

6 M.N. Boeve and G.M. van den Broek, The Programmatic Approach; a Flexible and Complex Tool to Achieve Environmental Quality Standards, Utrecht Law Review, volume 8, issue 3, November 2012, p. 78 . 
$0.05 \mathrm{~mol} / \mathrm{ha} / \mathrm{yr}$ were not registered. It was assumed that these small projects together could not have a significant effect on the protected sites.

\subsection{Allocation of the Room for Development}

All priority projects in the first segment were included in the Annex to the nature conservation regulation. The Minister determined which projects would be included in the Annex. The Annex could be updated twice a year. The PAS stated what kind of projects could be included in the Annex, though there was no transparent application procedure. The initiator of a project could not file an application for this segment. In practice, an initiator made an informal request for the project to be added to the Annex. Since this was an informal procedure, if such a request was rejected the initiator could not appeal against this decision in the administrative courts.

The provincial executive of the twelve Dutch provinces allocated the free room for development in the second segment. The allocation of this room for development was limited in time; in the first half of the six-year time span, $60 \%$ of the available room for development could be allocated and in the second half, the remaining $40 \%$ could be allocated. The initiator of a project could apply for a permission (toedelingsbesluit). Policy rules had been drawn up by the provincial authorities. All policy rules stated that the allocation method was 'first come, first served' so that the segment was divided based on the date when a complete application was filed.

The provincial policy rules could also contain grounds to refuse a permission, in addition to the grounds for refusal contained in the Nature Protection Act. Most policy rules had a maximum amount of mol that could be granted for a project. In September 2018, the province of North Brabant amended its policy rules by adding sustainability requirements. Permission would only be granted if all energy-saving measures had been taken that had a payback period of six years or less. According to these policy rules, the use of energy was linked to the emission of ammonia and therefore the largest direct or indirect source of emission and cause of nitrogen deposition. Therefore, this ground for refusal was added to the policy rules. As far as we are aware, the other provinces did not have a similar ground for refusal.

\subsection{Monitoring System}

The PAS had a time span of six years. During that period, the allocation of the available amount of nitrogen deposition was partially registered and the effects on the Natura 2000 sites were monitored. If this annual monitoring showed that the objective of sufficient reduction of nitrogen deposition was at risk, the PAS could be adjusted by adding more measures or by limiting the 
remaining room for development. ${ }^{7}$ According to the PAS, this system of monitoring and adjustment safeguarded the functioning of the programmatic approach within certain embedded margins. Moreover, it did not compromise the conclusion of the appropriate assessment that the PAS would not adversely affect the integrity of the sites concerned. In this respect, the Council of State has ruled that this system of monitoring and adjustment can only have an additional and controlling function. It does not alter the obligation under Article 6(3) of the Habitats Directive to ensure that there is no reasonable scientific doubt as to the absence of adverse effects on the protected sites as the result of the plan or projects considered. ${ }^{8}$ With reference to the precautionary principle, the Council of State specified that though a certain level of uncertainty is inevitable, this level may not be so high that the obligations under Article 6(3) of the Habitats Directive will no longer be met.

\section{3}

\section{The Instrument of the Programmatic Approach}

\subsection{Programme or Programmatic Approach}

Several European Directives, such as the Water Framework Directive ${ }^{9}$ and the Air Quality Directive, ${ }^{10}$ prescribe policy instruments in various forms. By virtue of Article $288 \mathrm{TFEU}$, discretion is provided to the Member States to implement Directives in their national legal system. They are free to choose the form and method to achieve the prescribed result, but this discretion can be limited by the imposition of specific measures or standards and deadlines in Directives. Given this discretion, the difference between a programme and a programmatic approach becomes relevant. A programme is usually a policy instrument. ${ }^{11}$ In many Directives programmes are prescribed and these programmes have to contain measures and criteria for the authorisation of projects, but they do not function as a binding legal assessment framework for decision-making. A programmatic approach is more than a mere policy instrument, because it includes a direct combination of legislation and policy and

7 Administrative Jurisdiction Division of the Council of State (Afdeling bestuursrechtspraak van de Raad van State (ABRvS)) 17 May 2017, ECLI:NL:Rvs:2017:1259.

8 Supra note 6, para. 14.2.

9 European Parliament and Council Directive 2000/6o/EC establishing a framework for Community action in the field of water policy, OJ $2000 \mathrm{~L} 327$.

10 European Parliament and Council Directive 2008/50/EC on ambient air quality and cleaner air for Europe, OJ $2008 \mathrm{~L} 152$.

11 See also E. Plambeck and L. Squintani, Rechtsbescherming tegen plannen en programma's in het omgevingsrecht in het licht van het Unierecht, SEW, no. 1, January 2019. 
provides a binding legal assessment framework for decision-making. ${ }^{12}$ The programmatic approach is not prescribed in EU secondary law, but it is a typical Dutch invention, mainly used for the implementation of Directives. In this context, Squintani and Van Rijswick make a distinction between programmatic approaches with a delinking effect and programmatic approaches without this effect, which we refer to as programmes. ${ }^{13}$ A programmatic approach with a delinking effect causes a breach between environmental quality standards and the authorization for a specific project. Individual projects can be permitted, as long as the programme as a whole ensures compliance and does not require an individual assessment. The PAS has such a delinking effect, providing the competent authorities with more freedom on how to achieve EU environmental goals. In line with the deregulation desired by the government, this delinking effect has increased the popularity of the programmatic approach in the Netherlands. A programmatic approach aims to reduce the administrative burdens on citizens and businesses because the instrument provides in the above mentioned delinking effect and functions as a binding legal assessment framework.

\subsection{The Key Features of a Programmatic Approach}

In order to function properly as a legal assessment framework and as an effective policy instrument, we believe that a programmatic approach must contain at least the following cumulative key features. In addition to the three legal key features already distinguished by Groothuijse and Uylenburg, we have identified three more key features. ${ }^{14}$ We derived these extra key features from the PAS itself. Firstly, an achievable and verifiable objective within a limited time span is required. This objective can be an environmental quality standard, like limit values for $\mathrm{PM}_{10}$ or nitrogen dioxide, or some other environmental goal, such as the favourable conservation status in the Habitats Directive. The PAs had a limited time span of six years $\left(2015^{-2021}\right)$, and within this time span its objective was limited to reducing nitrogen deposition to a level that prevents further deterioration of the Natura 2000 sites. After these six years, a second new

\footnotetext{
12 For the PAS, see Article 1.13 of the Nature Conservation Act (Wet Natuurbescherming) and the General Administrative Regulation on Nature Conservation (Besluit Natuurbescherming).

13 L. Squintani and H. van Rijswick, Improving Legal Certainty and Adaptability in the Programmatic Approach, Journal of Environmental Law, 2016, 28, 443-470.

14 F. Groothuijse and R. Uylenburg, Everything according to plan? Achieving environmental quality standards by a programmatic approach, New horizons in environmental and energy law series, EU environmental legislation: legal perspectives on regulatory strategies, 2014, Edward Elgar Publishing, p. 116-145.
} 
programmatic approach would have to be adopted for the period 2021-2027. $\cdot^{15}$ Boeve and Van den Broek conclude that a binding legal time span or deadline in a Directive limits the discretion of Member States to choose the kind of measures they have to adopt, because the effectiveness has to be guaranteed. ${ }^{16}$ If a Directive does not have a binding legal time span or deadline, the Member State has more discretion. By lack of a concrete deadline for achieving the favourable conservation status of sites concerned, the Council of State judged that the chosen level of ambition of the PAS stayed within the given margin of appreciation in the Habitats Directive. ${ }^{17}$ Secondly, a set of measures that results in a quantifiable fixed space or amount of environmental rights is necessary. An example of this fixed space or amount of rights was the room for deposition in the PAS. Thirdly, as Groothuijse and Uylenburg also stated, a programmatic approach must contain a legal obligation to carry out all the measures within the programmatic approach. Voluntary measures are by their nature unsuitable, because the effects of those measures will usually be uncertain. In this context, the Council of State therefore judged that the effects of the voluntary measures on the food used to feed cattle in the PAS were too uncertain to be taken into account. ${ }^{18}$

Fourthly, a measurable baseline situation - also referred to as autonomous or reference situation - and a limited geographical area are required. This does not mean that a programmatic approach is not a suitable instrument for transboundary environmental issues, but it limits the scope of measures for the national competent authorities. For example, nitrogen deposition in the Netherlands originates from various foreign and national sources, but the measures in the PAS inevitably only covered the national sources of nitrogen deposition, such as intensive livestock farming. In the PAS the chosen reference situation was the level of nitrogen deposition in $2014 \cdot{ }^{19}$ Fifthly, a programmatic approach needs a method of allocation. In the PAS the room for development needed to be allocated to various projects. As set out in section 2, the allocation method chosen in the PAS was 'first come, first served'.

Lastly, a programmatic approach needs a system of monitoring and adjustment. Groothuijse and Uylenburg rightly point out that monitoring may result in adding measures or cancelling projects, but if the monitoring shows better results than anticipated, it may also result in more harmful projects being

\footnotetext{
15 See Programmatische Aanpak Stikstof 2015-2021, p. 10, www.bij12.nl.

16 Supra note 6.

17 Supra note 7, para 8-8.2.

18 ABRvS 29 May 2019, ECLI:NL:RVS:2019:1603, para 20.13.

19 Supra note 7, para 11-11.6.
} 
allowed. ${ }^{20}$ The PAS also provided for annual monitoring and the possibility to add extra measures or limit the room for development. ${ }^{21}$ Squintani and Van Rijswick rightly point out that the degree of adaptability may effect legal certainty and Schoukens notes that already permitted activities should not be excluded from monitoring. ${ }^{22}$ Moreover, according to us the results of monitoring should even be a ground for revoking prior authorizations if monitoring shows that the objective of the programmatic approach cannot be reached within the given time span by mere adjustment. According to us, that risk is inherent for authorizations given under a programmatic approach in the context of the Habitats Directive and the precautionary principle. ${ }^{23}$ De Sadeleer even states that irreversible decisions are the antithesis of the precautionary principle. ${ }^{24}$ Effective and timely monitoring should be able to result in adjustment of the programmatic approach by adding measures or decreasing the fixed space or amount of rights and as a last resort, the revocation of given authorizations. Without these six features, the effectiveness of the programmatic approach cannot be verified and it will entail the risk of allocating too many rights in relation to the objective within the time span.

\section{4 \\ The PAs Case: the Habitats Directive Does Not Preclude a Programmatic Approach}

In the landmark PAS case, the CJEU gave a preliminary ruling based on several questions from the Dutch Council of State which arose after the PAS came into force in 2015 in the Netherlands. ${ }^{25}$ The CJEU ruled that Article 6(3) of the Habitats Directive does not preclude national programmatic legislation that allows the competent authorities to authorize projects based on an appropriate assessment in which a specific overall amount of nitrogen deposition has been assessed. The CJEU adds that an assessment with an overall evaluation such as the PAS makes it possible to better examine the cumulative effects of various projects, but stresses that all the requirements of Article 6(3) of the Habitats

\footnotetext{
20 Supra note 14, p. 125.

21 Supra note 7 , para 6.6 and 6.11.

22 Supra note 13 and 5.

23 The district court of East-Brabant ruled that a definitive permit based on the PAs still can be revoked if the appropriate assessment does not comply with Article 6(3) of the Habitats Directive, Rechtbank Oost-Brabant, 19 August 2019, ECLI:NL:RBов R:2019:4830.

24 N. De Sadeleer, Environmental Principles, from political slogans to legal rules, 2002, Oxford University Press, p. 222.

Supra note 1.
} 
Directive still have to be met. These requirements are only met if the national court has carried out a thorough and in-depth examination of the scientific soundness of this appropriate assessment, and reaches the conclusion that there is no reasonable scientific doubt as to the absence of adverse effects of each plan or project on the integrity of the sites concerned within the programmatic approach. The CJEU adds that conservation measures both within the meaning of Article 6(1) and preventive measures within the meaning of Article 6(2) of which the expected benefits are not certain at the time of the appropriate assessment, may not be taken into account. Although the CJEU does not preclude a programmatic approach based on the Habitats Directive, it has set a pretty high bar by holding on to its strict interpretation of the precautionary principle as described in Article 6(3) and the corresponding nodoubts criterion. ${ }^{26}$

On 29 May 2019, the Council of State, in compliance with the PAS case, gave its final judgment in the $P A S$ case. ${ }^{27}$ The Council ruled that the appropriate assessment of the PAS includes the expected benefits of source-directed measures, site-specific restoration measures and autonomous developments which were not ascertained and is therefore not in accordance with the precautionary principle as referred to in Article 6(3) Habitats Directive. Since the permits referred to the appropriate assessment on which the PAS is based, the Council annulled these permits. In the next section we will assess why the PAS was not in accordance with the precautionary principle and we will try to define under what conditions a programmatic approach would comply with this principle.

The Precautionary Principle and the Programmatic Approach

\subsection{The Precautionary Principle}

One of the leading principles in international and EU environmental law is the precautionary principle, but there is no uniform understanding of the meaning of this principle. ${ }^{28}$ Tridimas clarifies the difference between a right and a principle and notes that, whilst rights give rise to direct claims for positive action by the Union and national authorities, principles must be implemented by legislative or executive action at Union or State level and become material

26 See also L. Squintani, Balancing nature and economic interests in the European Union: On the concept of mitigation under the Habitats Directive, RECIEL, 2019,00; 1-9.

27 Supra note 18.

28 Ph. Sands, J. Peel, A. Fabra and R. Mackenzie, Principles of International Environmental Law, 2018, Cambridge University Press, p. 234. 
only for the purpose of the interpretation or judicial review of such acts. ${ }^{29}$ In EU law the legal basis for the precautionary principle is Article 191(2) TFEU and this principle is further defined in various Directives and Regulations. ${ }^{30}$ This principle is intended as a method to cope with scientific uncertainty on the effects of decisions on the environment and aims to regulate potential environmental risks. ${ }^{31}$ The precautionary principle is a risk management tool for decision-making in situations with scientific uncertainty. Risk management relates to the decision how much risk is acceptable and this decision may need a prior risk assessment to determine the risks. ${ }^{32}$ De Sadeleer calls this a two-step process of risk analysis which aims to provide a scientific base for decisions. ${ }^{33}$ Of course, not every decision has to be preceded by a risk assessment. Only if it is plausible that there is a potential and serious threat to the environment is such a risk assessment required. In this context Foster points out that there must be some minimum threshold in order for the precautionary principle to be applied, but this threshold still has to be identified in practice. ${ }^{34}$ De Sadeleer distinguishes residual risks, certain risks and uncertain risks. ${ }^{35}$ Residual risks are small or very hypothetical risks and certain risks are covered by the preventive principle. So only uncertain risks with some significance fall under the scope of the precautionary principle. If the threshold of uncertain risk with some significance is exceeded, the burden of proof shifts to the authority that wants to allow, or the party that wants to undertake, the potential harmful activity or activities. Instead of allowing these activities because their potential harmful effects are not known and the possible damage has not (yet) occurred, the authority or party has to deliver scientific proof on the magnitude of the effects of these activities before they are allowed and can be undertaken. The application of the precautionary principle should therefore start with a scientific evaluation, as complete as possible and, where possible, identifying the degree

29 T. Tridimas, Conclusion, The general principles of law, who needs them? In: Cahiers de Droit Européen, 2016-1, Bruylant, p. 19.

30 The principle applies not only to EU environmental law, but to all EU law, see Case T-584/13, Syngenta and Bayer/Commission, ECLI:EU:T:2018:280 and ECLI:EU:T:2018:279.

31 F.M. Fleurke, De lange mars van het voorzorgsbeginsel: de redding van de bij?, NtEr 2018, nr. $7 / 8$.

32 A. Randall, Risk and Precaution, 2011, Cambridge University Press, p. 43-55.

33 N. de Sadeleer, Precautionary principle in EU Law, AV\&S 2010, 24.

34 C.E. Foster, Science and the Precautionary Principle in International Courts and Tribunals, Expert Evidence, Burden of Proof and Finality, 2011, Cambridge University Press, p. 257.

Supra note 25, p. 157 . 
of scientific uncertainty. ${ }^{36}$ Scientific uncertainty comes in multiple forms. Aven distinguishes uncertainty between the activity and its possible effects on the environment (cause-effect relationship), uncertainty about the probability of the risk and uncertainty about the accuracy of the prediction model. ${ }^{37} \mathrm{Sci}-$ entific uncertainty must be distinguished from plain ignorance. ${ }^{38}$ In contrast to scientific uncertainty, ignorance implies unawareness of the existing body of knowledge, while scientific uncertainty refers to the many things we do not (yet) know. Environmental scientific uncertainty is often due to the complexity and variability of ecosystems, which makes long-term predictions intrinsically difficult. However, this does not release authorities from their duty to examine the existing body of scientific data and is no licence for ignorance. As a result, the precautionary principle is inextricably linked to the burden of proof to substantiate the potential risks and the probability of those risks for the environment.

The precautionary principle is specified in numerous Regulations and Directives, such as the Habitats Directive, and allows protective measures to be taken without having to wait until the reality and seriousness of those risks become fully apparent. ${ }^{39}$ The principle does not require absolute proof of absence of all risks, but requires the best available scientific data to manage the acceptable risks and a cautious worst-case scenario approach to avoid underestimating potential environmental risks. In the Du Pont de Nemours case the General Court (EGC) ruled that the adoption of a preventive measure, or conversely, its withdrawal or relaxation on the basis of the precautionary principle cannot be made subject to proof of the lack of any risk, in so far as such proof is generally impossible to give in scientific terms since zero risk does not exist in practice. ${ }^{40}$ The lack of full scientific certainty distinguishes the precautionary principle from the prevention principle, which applies in situations where it is certain that environmental damage will occur or where a quantifiable risk exists. ${ }^{41}$ As it is a principle and not a rule, the precautionary principle does not have an unequivocal definition and must gain substance through

36 Commission of the European Communities, Communication from the Commission on the precautionary principle, Brussels, 2 February 2000, СОМ (2000) 1 final, p. 3 and 16.

T. Aven, On Different Types of Uncertainties in the Context of the Precautionary Principle, Risk Analysis, Vol 31, No. 10, 2011.

38 A. Trouwborst, Precautionary Rights and Duties of States, 2006, Koninklijke Brill N.V., Leiden, p. 71-99.

39 Case T-31/o7, Du Pont de Nemours a.o./Commission, ECLI:EU:T:2013:167.

40 Supra note 39, para 140.

41 W.Th. Douma, The Precautionary Principle, its Application in International law, European Law and Dutch Law, 2003, dissertation, University of Groningen. 
interpretation by authorities and courts. In principle, the competent authorities determine which risks are acceptable and which measures should be taken, but they must take into account the required high level of protection of the environment and the case law of national courts, the CJEU and the EGC. According to De Sadeleer it is not up to the scientists to decide on the acceptable level of risk and the authorities must therefore enjoy a degree of discretion in regard to risk assessment and proportionality of the decision. ${ }^{42}$

In the Waddenzee case, the CJEU ruled that the authorization criterion laid down in Article 6(3) of the Habitats Directive integrates the precautionary principle and makes it possible to effectively prevent adverse effects on the integrity of protected sites as the result of the plan or projects considered. ${ }^{43}$ With reference to the precautionary principle, the CJEU stresses in the PAS case that the assessment carried out under the first sentence of Article 6(3) of the Habitats Directive cannot have lacunae and must contain complete, precise definitive findings and conclusions capable of removing all reasonable scientific doubt as to the effects of the plans or the projects, and concludes that the appropriate assessment for the PAs must also meet these requirements. ${ }^{44}$ In the Finnish wolf case the CJEU ruled that, in accordance with the precautionary principle enshrined in Article 191(2) TFEU, if after examining the best scientific data available, significant doubt remains as to whether or not a derogation will be detrimental to the maintenance or restoration of populations of endangered species at a favourable conservation status, the Member State must refrain from granting or implementing that derogation. ${ }^{45}$ Given the complexity and vulnerability of ecosystems, the rapid decline of biodiversity in Europe and the often poor conservation status of protected species and habitats, this strict application of the precautionary principle by the CJEU in the context of the Habitats Directive is understandable. Especially in areas with serious and long-term critical load exceedances, like many Dutch Natura 2000 sites. $^{46}$ However, it also entails a risk of paralysing decision-making and stifling economic development and legal innovation. ${ }^{47}$ This risk arises by overestimating the predictive validity of scientific models for evaluating risks in combination

\footnotetext{
42 Supra note 24, p. 197-199.

43 Case C-127/02, Landelijke Vereniging tot Behoud van de Waddenzee a.o. $v$ Staatssecretaris van Landbouw, Natuurbeheer en Visserij, ECLI:EU:C:2004:482.

44 Supra note 1.

45 Case C-674/17, Finnish wolf, ECLI:EU:C:2019:851.

46 A.B. van den Burg, Blijft de rekening van stikstofemissie nu nog bij de natuur liggen?, Milieu \& Recht 2019/19, p. 113-114.

47 T. Arnoldussen, The Precaution Controversy: an Analysis through the lens of Ulrich Beck and Michel Foucault, Recht der Werkelijkheid 2016 (37) 3, p. 95-96.
} 
with a zero-risk approach. Here tension arises between the programmatic approach and the precautionary principle, because predictive validity is steadily lost as the model's forecasts are projected further into the future. ${ }^{48}$ Inevitably, the longer the chosen time span of a programmatic approach, the more scientific uncertainty there will be. The same goes for the chosen scope of a programmatic approach. The wider the scope of a programmatic approach, the more scientific uncertainty there will be as a result of an increase in variabilities.

The PAS and its appropriate assessment had a total time span of six years and covered approximately 120 different Dutch sites. A certain amount of scientific uncertainty will therefore be inevitable and, given the precautionary principle, that uncertainty as such is not a problem. But it does mean that assessing the cause-effect relationship between the various projects and measures and their effects on the different sites becomes increasingly difficult and that the accuracy of the prediction model that underlies the programmatic approach will inevitably decrease. As the precautionary principle requires a sound risk assessment prior to the authorization of the projects, retrospective monitoring cannot replace this assessment and can only serve as an additional measure to safeguard the outcome of this assessment. A monitoring system is not a means to reduce the burden of proof beforehand, and does not release the obligation to remove all reasonable scientific doubt on the effects of all projects in the appropriate assessment. So the role of retrospective monitoring in the Habitats Directive is quite limited and rightly so.

\subsection{Is the PAS in Accordance with the Precautionary Principle?}

The PAS contained a number of elements that are at odds with the precautionary principle as contained in Article 6(3) of the Habitats Directive. By opting for a complex programmatic approach with a twofold objective, a time span of six years and a national scope, the level of scientific uncertainty inevitably became very high; higher than is allowed by established CJEU case law. The CJEU requires a level of proof that is mainly suitable for one or a relatively small number of individual projects that will be executed within a short period of time. This burden and standard of proof is a result of the strict application of the precautionary principle of the CJEU, as the Council of State also noted in its final judgment. ${ }^{49}$ The PAS case is somewhat contradictory to the extent that the CJEU ruled that a programmatic approach can be in accordance with

48 See also D. Steel, Philosophy and The Precautionary Principle, Science, Evidence and Environmental Policy, 2014, Cambridge University Press, p. 106.

49

Supra note 18 , para 17.5 . 
Article 6(3) of the Habitats Directive and might even be preferable if cumulative effects of various projects can be examined. However, the CJEU actually provides very little room for a programmatic approach by demanding an assessment that ensures that there is no reasonable scientific doubt as to the absence of adverse effects of each plan or project within this programmatic approach. The Council of State concluded on the basis of the PAS case that only fully implemented measures, of which the benefits have been established, can be taken into account in an appropriate assessment. These measures must have their beneficial effects before the projects in the programmatic approach have their adverse effects. ${ }^{50}$ Kaajan has noted that a less ambitious PAS might be compatible with Article 6(3) of the Habitats Directive if less room for development were provided and the PAS worked with a shorter time span..$^{51}$ This would reduce the amount of scientific uncertainty because the predictive validity of an appropriate assessment for such a programmatic approach would be higher. This also means that a large part of the twofold objective would have to be abandoned.

Another solution is suggested in the opinion of 25 July 2018 by Advocate General Kokott. She suggests that Article 6(4) of the Habitats Directive could be used as a legal basis for some projects in the PAs, but only if there are no alternative solutions and imperative reasons of overriding public interest, including those of a social or economic nature. However, not all projects within the current PAS will meet these requirements. For example, it seems hard to imagine that there would be an imperative reason of overriding public interest for expanding an individual intensive livestock farm in the vicinity of a protected site. In this context, Kokott stated that it appears difficult in general to recognize the interests of individual farms as imperative reasons of overriding public interest. An integrated approach like the PAS could however allow these individual interests to be classified in the public interest in agricultural development and respect for acquired rights. As agriculture is essential for the national food supply, it can (partially) qualify as an imperative reason of overriding public interest, but this does not mean that Article 6(4) of the Habitats Directive justifies expansion of livestock farming in the vicinity of vulnerable Natura 2000 sites where the annual nitrogen deposition is much higher than the critical loads. So this solution will inevitably have to mean a programmatic approach with less room for development, a much narrower scope and a shorter time span. The Council of State also sees opportunities for a programmatic

50 Supra note 18 , para 18.

$5^{1} \quad$ M.M. Kaajan, Het PAS-arrest; en nu? Milieu \& Recht 2019/18, p. 111. 
approach with a narrower scope limited to conservation and protective measures on the basis of Article 6( 1 and 2$)$ of the Habitats Directive. ${ }^{52}$

\subsection{Is the Allocation Method in Accordance with the Precautionary Principle?}

The PAS allocated the free room for development by way of 'first come, first served': the limited amount of environmental rights was granted based on the day of receipt of the applications. According to Kokott, in the light of the EU's environmental policy objective of ensuring a high level of environmental protection, as well as the precautionary principle and the principle of preventive action, it seems desirable that the alternatives to a project should be examined as comprehensively as possible. Such an approach would make it possible to select the project option which restricts the adverse environmental effects of that project to a minimum. ${ }^{53}$ We wonder whether the allocation method chosen in the PAS was in accordance with the precautionary principle for two reasons.

Firstly, in general the legal framework did not require the individual applicant to have reviewed several alternatives for the project and to file an application for the project with the least environmental effects based on the best available technology. As mentioned in section 2, only the province of North Brabant had set sustainability requirements. In North Brabant permission could only be granted if all energy-saving measures had been taken that have a payback period of six years or less. The ratio of this requirement was that the use of energy is linked to the emission of nitrogen oxides. In our opinion, all provinces should have introduced sustainability requirements. Especially since the favourable conservation status has not yet been achieved, it is remarkable that individual projects were permitted while alternatives to the project consisting of beneficial source-directed measures were available.

Secondly, the allocation method of first come, first served cannot select the 'best project', since the application date is the decisive selection criterion. We wonder whether a tender procedure that compares several projects on their environmental impact and, the secondary goal of the $P A S$, their benefits for the Dutch economy, would not have been a more suitable procedure in light of the precautionary principle. Such a procedure could, for instance, also favour innovative forerunners. By choosing first come, first served as the allocation method, a farmer who has not invested in the most modern stables could get permission to expand because he filed his application one day prior to a farmer

\footnotetext{
$5^{2} \quad$ Supra note 18 , para 28.1 .

53 Opinion AG Kokott Case C-461/17 Holohan.
} 
who has already built modern environmental-friendly stables. A comparative allocation method could favour such a forerunner who has invested in reducing his environmental impact. On the other hand, it must be stated that the Dutch government has introduced source-directed measures in several regulations. These regulations, for instance, contain minimum emission requirements that must be met by farmers. The crucial question, therefore, is whether these minimum requirements were sufficient to justify the first come, first served allocation method? Or does the precautionary principle require that permission can only be granted after it has been assessed whether an additional measure could be taken in an individual project, for instance by comparing several applications to each other?

We would like to stress that the fact that the Dutch PAS was not in accordance with the precautionary principle, does not mean that a programmatic approach cannot be a useful instrument. Both the CJEU and the Council of State emphasized that an assessment with an overall evaluation such as the PAS does make it possible to examine the cumulative effects of various projects in a better way. If only the measures that comply with the precautionary principle are taken into account, the room for development that is then calculated if present - can still be allocated by using the programmatic approach. Such an overall approach creates a transparent allocation system that can be beneficial for both the environment and the economy. In addition, a suitable allocation system can contribute to the achievement of the environmental objectives. A programmatic approach is ultimately preferable to an application procedure where it is not at all transparent how much room for development is available and how this will be allocated.

This section will answer the question whether the PAS, and more specifically the allocation method of the PAS, was in accordance with the freedom to conduct a business as protected by Article 16 CFR. The European Union Agency For Fundamental Rights (FRA) describes that the essence of the freedom to conduct a business is to enable individual aspirations and expression to flourish, and to promote entrepreneurship and innovation, which in turn is indispensable for sustainable social and economic development. ${ }^{54}$ So far, most case law and literature concerns the relationship between the right to conduct a

54 FRA, Freedom to conduct a business: exploring the dimensions of a fundamental right, 2015 . 
business and labour and social rights. ${ }^{55}$ However, we believe that this right should also be taken into account if scarce environmental rights are allocated. FRA states that 'conducting a business' includes any legitimate form of profit-making activities conducted by one or several individuals 'in company'. ${ }^{6}$ The right seems to encompass the full 'life-cycle' of such activities, for instance from setting up a company, through operating one, to insolvency or closing a business. ${ }^{57}$ In principle, starting a business should merely require registering it, by notifying the relevant (local) authority and not require a permit to establish or conduct the business. ${ }^{58}$ It is obvious that with this broad definition, the requirement to apply for a permit in accordance with the PAs limits the freedom to conduct a business.

\subsection{Applicability of the CFR}

Article 51 CFR states that the provisions of the CFR are only applicable to the Member States when they are implementing Union law. As explained, the PAS is a national instrument to implement the Habitats Directive. With the PAS, the Netherlands aimed to achieve the favourable conservation status as referred to in the Habitats Directive. In addition, projects were authorized under the PAS, since it qualified as an appropriate assessment as required by the Habitats Directive. Therefore, in our opinion, a programmatic approach should not only be in accordance with the Directive and the TFEU, but also with the CFR. Subsequently, conformity with the CFR can also be submitted to the Dutch Courts. This follows from a 2016 case of the CJEU in which the CJEU ruled that national procedural law must be in accordance with Article $47 \mathrm{CFR}$, and therefore requires that environmental organizations must be able to start legal proceedings to secure judicial review of compliance by the competent national authorities with their obligations arising from Article 6(3) of the Habitats Directive. ${ }^{59}$ For the Netherlands, the possibly to invoke this right before court is relevant, since the Dutch constitution contains only more general references

55 For instance: G. Stefano, Freedom to Conduct a Business and EU Labour Law, European Constitutional Law Review, 2018 (1), p. 172-190, and A. Usai, The Freedom to Conduct a Business in the EU, Its Limitations and Its Role in the European Legal Order: A New Engine for Deeper and Stronger Economic, Social, and Political Integration, German Law Journal 2013(9), p. 1867-1888.

56 Supra note 54, p. 11.

57 According to Gill-Pedro, the freedom to conduct a business seems to develop from an understanding of freedom as non-domination towards a freedom as non-interference (E. Gill-Pedro, Freedom to Conduct Business in EU Law : Freedom from Interference or Freedom from Domination?, European Journal Of Legal Studies, 2017 (2), p. 103-134).

58 Supra note 54, p. 33 .

59 Case C-243/15, Zoskupenie II, ECLI:EU:C:2016:838. 
that might not necessarily be understood as directly granting the freedom to conduct a business as an enforceable fundamental right. ${ }^{60}$

\subsection{A Fundamental Right, but Not an Absolute Right}

Article 16 CFR states that the freedom to conduct a business in accordance with Union law and national laws and practices is recognized. In the Explanations relating to the Charter of Fundamental Rights, ${ }^{61}$ it is stated that the Article is based on CJEU case law, which has recognized freedom to exercise an economic or commercial activity, and Article $119 \mathrm{TFEU}$, which recognizes free competition. According to the CJEU, the reference in Article 16 CFR to European Union law must be understood as meaning that Article 16 CFR refers, inter alia, to Article $49 \mathrm{TFEU}$, which guarantees the fundamental freedom of establishment. ${ }^{62}$ The freedom to conduct a business freedom is included in the title of the Charter with other rights such as liberty and security, privacy, and freedom of expression. Verburg stresses that Article 16 creates a fundamental right and not 'just a principle'. He therefore believes that the freedom to conduct a business might lead to a stricter obligation to state reasons in national law. ${ }^{63}$ FRA also notes that with the Charter becoming legally binding in 2009, this right has come to occupy a more prominent role. ${ }^{64}$ It is also noteworthy that there are no explicit parallels to Article 16 in international human rights law instruments, even though the European Court of Human Rights has recognised elements of the right in for instance the right to property. ${ }^{65}$ We therefore agree with Groussot et al. that Article 16 is potentially a powerful tool for challenging both Union decisions and Member States' measures. ${ }^{66}$

However, the freedom to conduct a business is not an absolute right which cannot be subjected to legitimate restrictions. In the Explanations, it is emphasized that the right may be subject to the limitations provided for in Article $5^{2}$ CFR. This Article states firstly that any limitation on the exercise of the rights and freedoms recognised by this Charter must be provided for by law

\footnotetext{
6o Supra note 54 , p. 27 .

61 Explanations relating to the charter of fundamental rights dated 14 December 2017, 2007/C 303/02, OJ C 303/17.

62 Case C-367/12, Sokoll-Seebacher, ECLI: EU:C:2014:68.

63 L.G. Verburg, Ter Visie - Het grondrecht van de vrijheid van ondernemerschap: een nieuw geluid?, TAO 2017 (3), p. 115-117.

64 Supra note 54, p. 9.

65 Supra note 54, p. 10. See for more on the Habitats Directive and the right to property: H. Schoukens, Ongoing Activities and Natura 2000, JEEPL 2014 11(1), pp. 1-30.

66 X. Groussot, G.T. Pétursson and J. Pierce, Weak Right, Strong Court - the Freedom to Conduct Business and the EU Charter of Fundamental Rights, Research Handbook on EU Law and Human Rights, 2017, p. 326-344.
} 
and respect the essence of those rights and freedoms. Secondly, these limitations are subject to the principle of proportionality and may therefore be made only if they are necessary and genuinely meet objectives of general interest recognised by the Union or the need to protect the rights and freedoms of others. The freedom protected by Article 16 might therefore lead to an obligation for the Dutch State to state reasons why the PAS is necessary and proportionate.

The CJEU has already answered several questions referred for a preliminary ruling regarding Article $16 \mathrm{CFR} .{ }^{67}$ In these judgments, the CJEU assesses whether the limitation of the right is justified. For instance, in the Pillbox 38 case the CJEU ruled that a prohibition on commercial communications for electronic cigarettes does not allow economic operators to promote their products and therefore constitutes an interference with the freedom of those operators to conduct a business. However, according to the $\mathrm{CJEU}$, the freedom to conduct a business does not constitute an unfettered prerogative, but must be examined in the light of its function in society. The freedom to conduct a business may thus be subject to a broad range of interventions on the part of public authorities which may limit the exercise of economic activity in the public interest. That circumstance is reflected, inter alia, in the way in which the CFR requires the principle of proportionality to be implemented. The CJEU noted that the limitation at issue did not affect the essence of the freedom to conduct a business. The prohibition did not prevent economic operators from manufacturing and marketing electronic cigarettes and refill containers in compliance with the conditions laid down in that regard by the Directive. Also, the interference found did not exceed the limits of what is appropriate and necessary to achieve the legitimate objectives pursued by the Directive in question. It is particularly relevant to the question of the proportionality of the PAS that in the Pillbox 38 ruling it is stated that additional scientific studies regarding the health risks of electronic cigarettes were necessary. Therefore, the EU legislature had to take account of the precautionary principle. This precautionary principle justifies the adoption of restrictive measures. The validity of the Directive with regard to the principles of proportionality should be examined in the light of those considerations regarding the precautionary principle. ${ }^{68}$ In light of the Pillbox 38 case, we consider it likely that the CJEU would rule that the limitation of the freedom to conduct a business by the PAS was necessary and proportionate. As extensively clarified by the Dutch State, the PAS was deemed necessary as a comprehensive system to achieve the conservation objectives. Protection of

67 For instance Case C-101/12, Schaible, ECLI:EU:C:2013:661.

68 Supra note 4 . 
the environment in general and the Habitats Directive more specifically, serve an objective in the general interest that can justify the limitation of this freedom. Also, as elaborately explained in the previous section, the precautionary principle plays an important role in the Habitats Directive in general, and the PAS in particular. A programmatic approach can therefore be a proportionate measure that can justify the limitation of the freedom to conduct a business.

However, a more complex question is whether the allocation method chosen in the PAS is also a proportionate measure. Noteworthy in this context is the ruling in the Spika case, since it concerns the question whether the allocation method for fishing methods is in accordance with Article 16 CFR. ${ }^{69}$ The CJEU assesses whether the method of allocation of fishing opportunities, which is based principally on historical share, goes beyond what is necessary to achieve the objectives pursued by the national legislation at issue. The CJEU concludes that Lithuania does not reserve fishing opportunities solely for historical operators on the basis of their respective historical shares but, in addition, allows for those shares to be weighed on the basis of a number of objective factors. Such factors are environmental criteria, in particular, or criteria which contribute to the development of the local economy. This method of allocation, therefore, does not go beyond what is necessary to achieve the objectives of general interest pursued by the national legislation at issue in the main proceedings and, consequently, it does not infringe on the principle of proportionality. The explanatory memorandum to the PAS does not emphasize why the method of allocation laid down in the PAS is necessary and proportionate. Therefore, we will look into that in the next section.

Interestingly, the principle of proportionality is a general principle of $\mathrm{EU}$ law. The CJEU already ruled that measures based on the Habitats Directive must be in accordance with this principle. ${ }^{70}$ According to Advocate General Kokott, Article 6(4) gives concrete expression to the principle of proportionality. Therefore, measures adopted may not exceed the limits of what is appropriate and necessary in order to attain the objectives legitimately pursued by the legislation in question; if there is a choice between several appropriate measures, recourse must be had to the least onerous, and the disadvantages caused must not be disproportionate to the aims pursued. ${ }^{71}$ If Kokott is right, this could indicate that if the PAS would have been in accordance with Article 6(4) of the Directive, it would also have been in accordance with the principle

69 Case C-540/16, Spika, ECLI:EU:C:2018:565.

70 Case C-2/10, Azienda Agro, ECLI:EU:C:2011:502.

71 Opinion AG Kokott, Case C-342/05, Commission/Finland, ECLI:EU:C:2006:752. See also: Opinion AG Kokott, Case C-127/02, Waddenzee, ECLI:EU:C:2004:6o. 
of proportionality. However, in our opinion, the answer to the question whether a measure that harms a Nature 2000 site is proportionate, might differ from the question whether a measure that limits the freedom to conduct a business is proportionate, especially if one looks at the proportionality of the allocation method.

\subsection{Is the Allocation Method of the PAs in Accordance with Article 16 CFR?}

As stated in the previous section, we feel that the PAS was necessary to protect the environment and might therefore limit the freedom to conduct a business. The precautionary principle can also make a programmatic approach proportionate. In this section, we will assess whether the limitation of the freedom to conduct a business by the PAS was also proportionate in light of the allocation method chosen.

As explained in section 2, the room for development in the PAS was divided into two segments. For the first segment, there was no transparent application procedure. It was up to the Minister to decide if a project was a priority project and whether it could be included in the Annex to the Nature conservation regulation. The CJEU has ruled that when assessing whether a national administrative authorization scheme is in accordance with Article 56 TFEU, the scheme must be based on objective, non-discriminatory criteria known in advance, in such a way as to adequately circumscribe the exercise of the national authorities' discretion..$^{72}$ We believe that the allocation of the first segment did not meet these requirements. It could be argued that these requirements are not applicable, since the Annex is not an authorization scheme. However, since the Annex did not only consist of government projects such as road reconstructions and dike elevations, but also the expansion of industrial sites in general and even the realization or transformation of specific plants owned by private companies, this raises the question: can a private company ask to be included in the Annex and if so, what criteria are applicable? These criteria are not made public.

For the second segment, the allocation method was 'first come, first served'. As stated before, this method is a relatively simple allocation method. Other allocation systems, especially a tender procedure, are more complex. Not all entrepreneurs will be able to file extensive project plans. In addition, if a tender procedure is organized only periodically - for instance once a year - this could have as a consequence that companies can only start or expand their businesses periodically. These arguments can justify the allocation method

72 Case C-338/og, Yellow Cab, eCLI:EU:C:2010:814, and Case C-470/11, siA/Rigas, ECLI:EU:C: 2012:505. 
chosen. However, the ruling of the CJEU in the Bressol case might point in another direction. ${ }^{73}$ In this case, the Court answered the question whether restrictions on access to higher education are in accordance with the principle of freedom of movement for students. The Court ruled that the restrictions must be limited to what is necessary in order to obtain the objectives pursued, and must allow sufficiently wide access by those students to higher education. The Court remarks that it is for the referring court to ascertain whether the selection process for non-resident students is limited to the drawing of lots and, if that is the case, whether such means of selection, based not on the aptitude of the candidates concerned but on chance, is necessary to attain the objectives pursued. If we look at the PAs, the allocation method 'first come, first served' was also to a certain extent based on chance, namely the application date. A tender procedure might be more suitable to achieve the goals of the PAS. In a tender procedure, the projects could be ranked according to their environmental impact. As stated in the previous section, this would be in line with the precautionary principle. In addition, a tender procedure could also rank projects according to their economic impact. It could, for instance, be assessed which projects create economic growth and jobs. We have no knowledge of research by the Dutch government on the necessity and proportionality of the allocation method chosen. To be in accordance with Article 16 CFR and the abovementioned case law, this should be clearly substantiated.

Finally, it is noteworthy that the provincial policy rules stated that an activity that was permitted under the PAS had to be realized within two years. If not, the permission can be revoked or altered. This competence is important in light of the effective and timely monitoring of the programmatic approach in general and the allocation of the environmental rights in particular. The granting of environmental rights to one initiative might lead to the refusal of the application of another initiative. From the perspective of environmental protection, it could be argued that it does not matter that permitted initiatives are not carried out since less emissions will benefit the environment. However, the PAS has a second objective: economic growth. Revoking a granted permission in the event of non-execution contributes to this second objective and subsequently to the proportionality test of Article 16 CFR.

To conclude, the overall approach of a programmatic approach can create a transparent allocation system. It can therefore contribute to an instrument that is still beneficial to the environment, but also leads to a proportionate restriction of the freedom to conduct a business. However, it can be questioned whether the Dutch PAS was in accordance with Article 16 CFR. If a Member State would consider introducing a programmatic approach, we recommend 
that it reflects on and states reasons why this programmatic approach in general, and the allocation system particular, is proportionate.

\section{$7 \quad$ Concluding Remarks}

The CJEU is of the opinion that Article 6(3) of the Habitats Directive and the precautionary principle do not preclude a programmatic approach, but at the same time the CJEU ruled that all the requirements of Article 6(3) still have to be met. This means that the overall appropriate assessment must substantiate that each plan or project within the programmatic approach will not adversely affect the Natura 2000 site or sites. If the time span covers several years, and the scope of the programmatic approach is wide, scientific uncertainty will inevitably increase because the cause-effect relationship between the projects and the predicted effects and the effectiveness of the measures within the programmatic approach become difficult to prove. The predictive validity of the appropriate assessment for such a programmatic approach will decrease, contain lacunae and no longer be able to provide complete, precise and definitive findings and conclusions capable of removing all reasonable scientific doubt as to the effects of the programmatic approach. The burden of proof simply becomes too heavy. This clearly follows from the final judgment of the Council of State on the PAS which, based on the precautionary principle, states that only fully implemented measures for which the benefits have been established can be taken into account in an appropriate assessment. To our mind, a less ambitious programmatic approach, with a shorter time span, less room for development and a narrower scope could be compatible with the precautionary principle because the scientific uncertainty will decrease significantly. The continuation of an amended programmatic approach is also recommendable in light of the freedom to conduct a business as protected by Article 16 CFR. The protection of the environment and the precautionary principle justify a limitation of this freedom, but the limitation must be proportionate. Since one of the goals of the PAS was to stimulate economic growth by allowing projects that would otherwise most likely not be realized, a programmatic approach contributes to a proportional limitation of the freedom to conduct a business. However, we note that it is debatable whether the allocation method 'first come, first served' chosen by the Dutch government is the most suitable method in light of both the freedom to conduct a business and the precautionary principle. It is now up to the Dutch government to decide whether it will adjust the PAS in such a way that it complies with both principles. 